\title{
Anyone speak Korean?
}

\section{Washington}

After a two-week search for Asian partners for the Superconducting Super Collider (SSC), US Department of Energy (DOE) officials returned last week with a 'surprise' letter of support from South Korea. But although DOE held a press conference at which deputy energy secretary W. Henson Moore interpreted the letter as Korea's intention to become a partner in the $\$ 8,000$ million accelerator project, it remains unclear what, if anything, Korean officials have actually promised.

DOE released a photograph showing US energy secretary James Watkins and Korean minister of science and technology Kunmo Chung exchanging a letter that can be seen to be written in Korean. On the back of the picture, the letter is identified as a formal acceptance by Korean President Tae Woo Roh of President George Bush's offer to become a partner in the SSC. When pressed, however, DOE officials admitted that they are not entirely sure what the document signifies. "We take it to mean that the Korean

\section{ACOST}

\section{Strategic reviews to be published}

\section{London}

RESPONDING to pressure from the House of Lords Science and Technology Committee, British prime minister Margaret Thatcher has decided that the government's Advisory Council for Science and Technology (ACOST) will publish a strategic review of British science and technology every three years.

Mrs Thatcher had earlier insisted that ACOST's advice should remain confidential. But Lord Flowers, chairman of the Lords committee, wrote to the prime minister on 6 March, arguing that the annual review of government funded research and development was inadequate to assess the progress and priorities of British science. Mrs Thatcher's reply says the new ACOST reviews will identify future issues to be examined in the public and private sectors.

The first review will be the responsibility of Sir Robin Nicholson, an industrialist who takes over as chairman of ASCOT from Lord Tombs for a three-year term beginning in July.

ACOST was established in 1987 at the suggestion of the House of Lords Science and Technology Committee, to advise the government on priorities for British science, including the application of research and international collaboration.

Peter Aldhous government is very interested in joining the project", Moore said.

A DOE spokesman says that the confusion arose because the Koreans had not supplied an English translation of the letter, and the initial US attempt at translation apparently missed some nuances.

On reflection, DOE has reinterpreted the letter to mean that Roh is considering the offer and will have an answer soon. Unfortunately, DOE refuses to release the text of the letter in either English or Korean, and the photograph is just a bit too indistinct for it to be possible to read more than scattered words.

Moore said that he had left the Koreans with a list of "appropriate ways they could discharge their partnership responsibilities". Although he did not specify what those ways were, he said that cash, magnets and other technology were all options (see Nature 345, 563; 14 June 1990).

Unexpectedly, Korea responded by giving DOE its own list of contributions it thought were appropriate. Sources who HUBBLE SPACE TELESCOPE

\section{Light at the end of the tunnel}

\section{Washington}

THE persistent vibration problems that have plagued the Hubble Space Telescope since its launch last month may soon be solved, National Aeronautics and Space Administration (NASA) officials said last week. A planned modification in the onboard control software is expected to correct the problem and allow the telescope to operate within design specifications in as little as a month, although a full schedule of scientific observations may not begin until late in the year.

NASA engineers have traced the vibration problem to thermal expansion of the telescope's large solar arrays. When Hubble moves from night to day and vice versa, the panels heat up unevenly and begin to sway. The 6 arc-second oscillations last for three to five minutes after the transition, during which time finetrack observations are difficult, says project manager Fred Wojtalik.

Because the telescope could be tested under the force of gravity only on the ground or with a computer simulator, the vibrations had not been fully anticipated. "The array gets a lot of heat quickly, and sees a thermal differential that is a lot larger than showed up in [pre-flight] analysis", Wojtalik says.

On-board control software was designed to dampen less severe mechanical oscillations, and tends to "overflow its stacks" when confronted with vibrations as large as those generated by the heated solar arrays, he says. met with Chung say that although the Korean government is indeed interested in collaborating on the SSC, the two countries still differ widely on terms. The United States wants money, they say, but Korea would rather provide manpower, skills and knowhow.

If Korea does join the SSC, it would be the project's first international partner. Given that the SSC is now expected to cost about twice the original estimate, DOE no longer considers India, which had earlier agreed to participate, bound to its promise.

Japan, DOE's chief target in the recent quest for partners, made few gestures of encouragement. But Moore denied the suggestion that the Japanese government had gone to great lengths to dissuade DOE from visiting, out of reluctance to being put in the position of having to say no. An advance DOE team had asked Japan whether Moore's team should come to make the formal request, Moore says, and Japan gave the green light. "I doubt that the Japanese are going to say that they have no intention of working together", he said. G. Christopher Anderson Although correcting the software simply requires changing several parameters to make the control loop "stiffer", NASA must thoroughly test the modifications to ensure that they do not have unexpected - and potentially disastrous - side effects. Testing is expected to take another three to five weeks, Wojtalik says. Once approved, the new software will be uploaded to Hubble.

The only other serious problems is in a radiation-sensitive portion of the guidance electronics. NASA engineers knew that the fine-lock system was less 'hardened' to radiation than the rest of the Hubble circuitry, but they decided to take the chance that it would not prove to be a problem. Once Hubble was in space, however, radiation in the South Atlantic Anomaly, the area of orbit where the Van Allen radiation belt comes closest to Earth, played havoc with the fine-lock electronics. The system would often reset itself when Hubble passed through the anomaly, requiring mission controllers to turn the system off and on again manually.

NASA's solution to the problem, while inelegant, seems to work. New software has been written to reset the fine-lock electronics five times a second throughout its orbit. Simulations indicate that Hubble's performance is not degraded by the manoeuvre. Indeed, when all the software changes are in place, NASA engineers expect to bring the telescope to within its original 0.007 arc-second stability goal.

G. Christopher Anderson 